\title{
Embracing The Future: What Can Accounting Graduates Expect?
}

Sheree M. Corkern, Mississippi College University, USA

Sandra B. Parks, Mississippi College, USA

Mark I. Morgan, Mississippi College University, USA

\begin{abstract}
This article informs accounting educators and graduates about key issues in the accounting profession of today, which has entered a new age, and accounting educators and advisors, old and new, must be informed about future prospects for students and make students aware of what they can expect as accounting graduates. Passing this knowledge to students early on provides them with advanced understanding of what the future holds for accounting professionals and will allow students to better embrace their future once they graduate.
\end{abstract}

This article emphasizes supply and demand, hiring and salary practices, and potential job opportunities for the accounting graduate. Information on the various certifications available for accountants and the interview process is included as well. The final section within the article offers insight into the future of the accounting profession. With this paper, educators and advisors gain knowledge to assist accounting students with their future career search process. Students will still need assistance to help them navigate the new environment that they are about to enter, but a clearer understanding of what to expect provides a better foundation on which to build a successful career.

Keywords: Accounting Profession; Accounting Graduate; Accounting Certifications; Accounting Careers; Interviews

\section{INTRODUCTION}

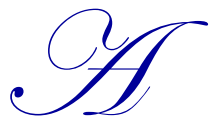

ccounting graduates have many questions about their futures in the profession. They want to know what types of jobs are available, what range of pay to expect, their options for where to work, the value of certifications, and what to expect of the interview process. In other words, they need to know what to expect after attaining their degree. The next decade in the accounting profession will be filled with many opportunities for both job and salary growth. When making decisions, accounting graduates must be able to assess the merits of the various opportunities and alternatives and evaluate the benefits and risks of each. They will need to identify their career goals and plan their strategy in achieving these goals. In college and working in an internship position, emphasis is placed primarily on performance and very little time or energy is given to exploring future opportunities. Timely dissemination of the information provided here can serve as a valuable resource for accounting graduates in overcoming hurdles and allow a newfound focus in developing their career paths.

\section{SUPPLY OF ACCOUNTING GRADUATES}

According to the AICPA "Survey 2011 of Trends in the Supply of Accounting Graduates and the Demand for Public Accounting Recruits", accounting enrollments continue to increase and have reached the 225,000 mark for the first time in history. This milestone represents an estimated 46 percent increase from the early 2000s. Not only have enrollments increased, but the number of accounting graduates has reached an all time high since the AICPA survey began in 1971, with 26,000 graduates in the 1971-1972 school year versus 68,000 graduates in the 2009-2010 school year. 
Also, according to the AICPA report, there is a concern that colleges and universities are struggling to keep the supply up due to the growing number of accounting programs that reject qualified applicants because they do not have the capacity to accept them. The report stated that 20 percent of AACSB-accredited accounting programs are turning away an average of 125 qualified applicants each year.

\section{HIRING OF ACCOUNTING GRADUATES BY CPA FIRMS}

The hiring and demand for accounting graduates slowed during the economic downturn and, according to CPA Trendlines, CPA firms cut an estimated 50,000 jobs in the first 20 months of this recession. However, hiring of accounting graduates is now on the rebound and there is expected to be a strong demand for the class of 2013. For example, in 1971, around 8,800 new accounting graduates were hired by CPA firms and in 2010, this number reached more than 33,000. According to the U.S. Bureau of Labor Statistics, the projected growth for accountants and auditors for the years 2010-2020 is around 16 percent. Employment of accountants and auditors is expected to grow from 1,216,000 for 2010 to $1,407,600$ for 2020.

Looking at a couple of the Big 4 firms, Deloitte LLP plans to hire 18,000 professionals in the United States and India in 2013 and Ernst \& Young expects to hire more than 10,000 experienced and entry-level financial services employees in the United States during the 2013 year. According to the current National Association of Colleges and Employers (NACE) survey, accounting is one of the top degrees in demand for 2013 and more than 70 percent of employers seeking business graduates are looking to hire accounting majors. Forbes.com recently ranked accountants as one of the top three jobs for 2013. U.S. News \& World Report cited a strong employment outlook and named the accounting profession as one of the best career choices.

Accounting continues to be one of the strongest sectors of the economy when it comes to hiring. According to CPA Trendlines, many accounting firms have reported difficulties in finding employees due to an existing shortage of these professionals.

\section{SALARIES OF ACCOUNTING GRADUATES}

All graduates are very interested in what they will be paid. According to a salary survey conducted by NACE, the National Association of Colleges and Employers, the 2013 average starting salary for accounting graduates was $\$ 53,300$. This figure represents more than a six percent increase over the previous year. According to a survey in Careers-In-Accounting.com, salaries for first-year entry-level accountants for the Big 4 Firms are around $\$ 55,000$ and for the overall sector, around $\$ 50,000$ to $\$ 70,000$. Some of the highest salaries are coming from finance and insurance firms, with an average starting salary of $\$ 67,500$ for financial manager positions.

\section{CAREER OPTIONS}

An accounting degree can lead to many different career options, such as taxation, audit, management, academia, information technology, financial planning, forensic accounting, and valuation services. Students can choose to work for public accounting firms, corporations, or governmental entities. They can even start their own businesses. Below are examples that only begin to identify the multitude of job opportunities available to the accounting graduate. To learn more in-depth detail about specific accounting jobs, a good starting point would be the Internet. Analyzing differences in the characteristics, benefits, and risks of various career tracks can help students choose the job that best suits their long-term goals.

\section{Governmental}

Many government departments and agencies hire accountants at the state and federal levels. Some of the more popular governmental jobs include positions with the Internal Revenue Service (IRS), Federal Bureau of Investigation (FBI), General Accounting Office (GAO), Armed Forces, State Department of Revenue, and county and city governments. 
An accounting degree is one of the preferred credentials for applicants to the FBI. Many crimes investigated by the FBI involve financial crime and fraud. Although the GAO national office is in Washington, D.C. and most of its employees work there, the GAO has other offices located in major cities across the country.

A few of the positions within the IRS that a student may desire to pursue include revenue agent, special agent, tax auditor, revenue officer, or taxpayer service specialist. There has been much discussion about the opportunities that will be provided to accountants as a result of the implementation of the Patient Protection and Affordable Care Act known as Obamacare. The IRS will be in charge of administering the new healthcare law, including overseeing tax credits and tax increases. The IRS has stated that the tax changes associated with this health reform are substantial and will present a major challenge because this new law represents the largest set of tax law changes in more than 20 years.

\section{Academia}

The American Accounting Association reports that there is an increased demand for those within the accounting industry who hold a $\mathrm{PhD}$ because older degree holders are retiring at a rate far greater than the supply of new degree holders entering the field. They estimate that between 500 and 700 accounting faculty per year are retiring while accounting $\mathrm{PhD}$ programs in approximately 100 universities in the United States are averaging around 140 graduates per year. In order to encourage more accounting graduates to pursue this career path, the Accounting Doctoral Scholars Program was established, and it will award a $\$ 30,000$ yearly stipend for a maximum of four years to qualified candidates. Many universities have even waived tuition for doctoral study and are offering health insurance coverage to attract candidates to enter their $\mathrm{PhD}$ programs.

\section{Public Accounting Firms}

Although there may be numerous classifications for accountants, the most common classification division is between public and private accountants. Students are often faced with the dilemma of choosing between the two classifications. The public accounting route includes exposure to more diverse work within different industries. Since public accountants serve multiple clients, this enables them to obtain a large base of accounting knowledge and the ability to understand how many different businesses operate. As a result of this broader experience, switching from public accounting to private accounting can be easier than the transition from private to public. Generally, public accountants will travel more and will have more varied work schedules as well as having to deal with the constant pressure of billable hours.

\section{Private}

Private accounting involves providing accounting services for one company rather than a public accounting firm, which sells accounting services to many companies. A private accountant has many choices when choosing which company and the type of company to go to work for. As a private accountant, job duties can vary within the same organization but can include the preparation of monthly financial reports, internal audits, budgeting, cost reports, or working on mergers and acquisitions analysis.

\section{Sole Practitioner}

The process of owning and operating a sole-practitioner business is easier than ever before because of Internet access, increasingly inexpensive software, and the ability to use shared office space. Much of the work can be done virtually. Before making the decision to become a sole practitioner, it is important to honestly assess whether or not you are prepared to make this transition financially and emotionally and to adhere to the stringent commitment level that will be required. This type of practice requires someone with entrepreneurial talents, high motivation, and the ability and desire to market the business. Such an endeavor will require extensive planning, hard work, perseverance, and investment. Owning a business can be lucrative and rewarding, but it is always challenging. 


\section{Certifications}

There are numerous professional certifications available for accountants, including Certified Public Accountant (CPA), Certified Valuation Analyst (CVA), Certified Management Accountant (CMA), Chartered Financial Analyst (CFA), Certified Financial Planner (CFP), Elder Care Specialist (ECS), Certified Fraud Examiner (CFE), Certified Internal Auditor (CIA), and Certified Information Systems Auditor (CISA). The next question is, "Will certification really make a difference in my career?" The short answer is, "Yes." According to Robert Half's, Guide to Certifications, there is a heightened demand for accounting professionals who have demonstrated their expertise and commitment to ongoing education by earning professional designations. The results of the Robert Half survey suggest that certifications do add value for career advancement and can provide numerous benefits, including improved career prospects and enhanced earning power. Also, according to the Robert Half Salary Guide, those earning professional credentials may receive starting salaries up to 10 percent above the market average. The survey also indicated that in the future, organizations are likely to place even more value on certifications as a means of differentiating top candidates. Specialization is very important in the accounting industry today.

\section{Interview}

The goal of the interview process is to aid in the analysis, assessment, and selection of the best candidate for the job. The hiring process is one of the most essential parts of a company's strategy, and many companies place an incredibly strong emphasis on it. The interviewer is seeking to hire employees who will be an effective match and add value to the company.

It is perplexing that some students spend 20 hours studying for one intermediate accounting exam and then spend one hour preparing for a job interview or show up without any preparation at all. It is understandable that students are tired and under stress in college, but they must be made to understand the great importance of interview preparation. Students must prepare for job interviews and give that process the level of priority it requires.

The interview can be a lengthy screening process that could include several interviews along with a social outing. It is a process of determining which applicant is most qualified and suitable for the position. Interviewers focus on getting to know the candidate's attitude, experience, knowledge, communication skill, and social behavior in order to determine which candidate will be successful in the available position.

Preparation is the key for the student to exude confidence and be successful. For some students, this is a nerve-wracking process. They need to understand that the more they prepare for this process, the less frightening it will be. There are many valuable resources available to the student, such as Resumeindex.com and Monster.com that can be helpful in the preparation for this process. A few helpful hints for the student:

1. Make a favorable first impression with a professional physical appearance.

2. Prepare a resume that is appealing and the best piece of work that you have ever produced.

3. Thoroughly research the specific entity that you are interviewing with.

4. Practice by anticipating the typical interview questions and developing suitable answers for each.

5. Brush up on your communication and etiquette skills.

6. Have questions ready to ask the interviewer.

7. Express your interest in the position.

8. Conclude by thanking the interviewer for taking the time to meet with you and adhere to the appropriate follow up procedures.

Keep in mind that the interview may be the best chance for the student to make a favorable impression and get the job they so desire. The interview provides the student with a selling opportunity that they need to be ready for. 


\section{LOOKING INTO THE FUTURE}

The next decade for the accounting graduate looks bright. At one time many wondered what the collateral damage to the profession would be after all of the accounting scandals that occurred during the early part of the century - WorldCom, Enron, HealthSouth, Tyco, Arthur Andersen, etc. Since these scandals, the accounting profession has been busy restoring public trust and increasing ethics awareness throughout its industry. In 2002, Congress passed the Sarbanes-Oxley Act that created the Public Company Accounting Oversight Board (PCAOB) to help protect investors and the public interest by promoting informative, accurate, and independent audit reports. This act requires that auditors of U.S. public companies be subject to external and independent oversight for the first time in history. All of these changes have resulted in increased business for the accountants.

According to the Intuit 2020 report on the future of the accounting profession, over the next decade the number of small and personal businesses in the U.S. will increase by more than 7 million, and this increase will result in the need for more accounting professionals. Globalization, international business, and an increasing percentage of Web-based businesses will require a broader range of services offered by accountants, such as knowledge of International Reporting Standards (IFRS) and foreign tax codes.

Also, the Intuit 2020 reported that women have been starting small businesses at twice the rate of men during the last decade. This places those women in a position as financial decision makers and makes them an important client segment. Additionally, the report predicts an increase in technology-consulting opportunities, such as security and privacy consulting, as well as data management for accounting professionals.

Another issue of great importance regarding the future for the accountant is the approaching retirement of the baby boomers. The U.S. Census Bureau has predicted that by 2030, one in five Americans will be over the age of 65 . Thus, the demand for financial planning, estate planning, and elder care services by accountants is expected to increase.

Accountants are no longer looked upon as bean counters and are much more involved in the strategic decision-making processes within organizations. To be adequately prepared for these new roles, accountants are required to possess strong technical skills, strong communication skills, and the ability to work with a team. In other words, to be successful and ready for the future, the accountant's knowledge and abilities must encompass more than just knowledge of Generally Accepted Accounting Principles.

In 2011, the results of the CPA Horizons 2025 study highlighted the key trends the accounting profession will face in the years leading up to 2025. Results indicated that the profession can expect to face the greatest impact from long-term trends such as technology, globalization, and expanded service offerings. According to the 2011 AICPA Chair, Paul Stahlin, "The overarching theme that emerged from the research is that the entire profession has an incredibly bright future. CPAs will continue to serve as trusted advisors helping others make sense of an increasingly complicated and ever-changing world."

Accounting graduates need to embrace the future with great expectations. They should always plan for the challenges and leverage the opportunities of the future. Be ready to change as the accounting industry changes. Never quit learning and always keep their virtues of integrity and trustworthiness high. After all, trust is the official hallmark of the accounting profession. It looks like a great time to be pursuing accounting as a career path. Businesses will always need accountants whether the times are good or bad. With a better understanding of what to expect, a future in accounting can be exciting and rewarding.

\section{AUTHOR INFORMATION}

Sheree M. Corkern is an Assistant Professor of Accounting at Mississippi College University. Her research interests involve pedagogical issues and the practical issues that surround the accounting industry. She teaches courses in intermediate accounting, principles of accounting, and accounting information systems. Mailing address: is Mississippi College, School of Business, P.O. Box 4014, Clinton, MS 39058. E-mail: corkern@mc.edu (Corresponding author) 
Mark I. Morgan is an Assistant Professor of Accounting at Mississippi College. His research interests include teaching methods for adult students, current trends in the accounting profession, and issues related to the study of fraud examination. He teaches auditing, graduate auditing, issues in accounting decision-making, fraud examination, and CPA review. Formerly a criminal investigator, he has considerable legal experience prosecuting fraudulent financial cases. Mailing address is Mississippi College, School of Business, P.O. Box 4014, Clinton, MS 39058. E-mail: morgan00@mc.edu

Sandra B. Parks is an Assistant Professor of Accounting at Mississippi College. Her research interests include pedagogical issues in the accounting profession. She teaches courses in intermediate accounting, cost accounting, and principles of accounting. Mailing address: is Mississippi College, School of Business, P.O. Box 4014, Clinton, MS 39058. E-mail: sparks@mc.edu

\section{REFERENCES}

1. American Institute of Certified Public Accountants. (2011). AICPA Survey 2011 edition of Trends in the Supply of Accounting Graduates and the Demand for Public Accounting Recruits. Retrieved from: http://www.aicpa.org/interestareas/accountingeducation/newsandpublications/downloadabledocuments/201 1trendsreport.pdf

2. American Institute of Certified Public Accountants. (2011). CPA Horizons 2025 Report. Issued by the AICPA CPA Horizons Advisory Panel. Retrieved from: http://www.aicpa.org/Research/CPAHorizons2025/Pages/CPAHorizonsReport.aspx

3. American Institute of Certified Public Accountants. (2011). Forward Looking Report Outlines Future of Accounting Profession. Retrieved from: http://www.aicpa.org/press/pressreleases/2011/pages/future-ofaccounting-profession.aspx

4. Barney, D. K., \& C. Bjornson. (n.d.) Governmental Accounting Career Opportunities. Retrieved from: http://www.newaccountantusa.com/newsfeat/ip/ip_gov.html

5. Bergner, J. (2009) Pursuing a Ph.D. in Accounting: Walking in With Your Eyes Open. Journal of Accountancy Retrieved May 19, 2013, from http://www.journalofaccountancy.com/web/pursuingaphdinaccounting

6. Boyle, D. M., B. W. Carpenter, D.R. Hermanson, \& M. O. Mensah. (2011). Understanding The Accounting and Auditing Faculty Shortage: Perceptions From Practitioners, Deans, and Faculty. Presented to ASBBS annual Conference, Las Vegas.

7. Buckstein, J. (n.d.) Recovery of the accounting profession post-Enron. Retrieved from: http://www.cgapdnet.org/Non_VerifiableProducts/ArticlePublication/RecoveryAccountingProfession/Reco veryAccountingProfession_p2.pdf

8. Careers-in-Accounting. (n.d.) Accounting: Salaries. Retrieved from: http://www.careers-inaccounting.com/acsal.htm

9. Gold, L. (2009). Becoming your own boss (Unabridged) Opportunities abound for young CPAs venturing out on their own. Accounting Today, 23(18), 1-45.

10. Guthrie, C. P., \& A. Jones, III. (2012). Job Burnout In Public Accounting: Understanding Gender differences Journal of Managerial Issues 24(4), 390-411.

11. Importance of Interview for Employers and Job Seekers. (n.d.) Retrieved from: http://kalyancity.blogspot.com/2011/07/importance-of-interview-for-employers.html

12. Inside Public Accounting IPA Special Report The 2012 IPA 100 Vol. 26, No. 8 August 2012 Retrieved from: http://www.blueandco.com/docs/top100_2012.pdf

13. Intuit. (2011). 2020 Report Future Of The Accounting Profession. Retrieved May 16, 2013, from http://http-download.intuit.com/http.intuit/CMO/intuit/futureofsmallbusiness/intuit 2020 report.pdf

14. NACE job outlook 2013. (2012). NACE Job Outlook 2013. In 2 Job Outlook 2013 National Association of Colleges and Employers. Retrieved from: http://www.unco.edu/careers/assets/documents/NACEJobOutlookNov2013.pd

15. Nimmo, K. (2012). Thousands of New IRS Agents Hired to Enforce Obamacare. Retrieved from: http://www.inflowars.com/thousands-of-new-irs-agents-to-be-hired-to-enforce-obamacare/

16. Nixon, R. (n.d.) The Future Of The Accounting Profession. Retrieved from: http://proactiveaccountants.net/images/FutureAccounting.pdf 
17. Pounder, B. (2012). Public vs. Private: A Very Blurry Line Strategic Finance. 94(1) 19-21.

18. Pubic Company Accounting Oversight Board (PCAOB). (n.d.) About the PCAOB. Retrieved May 11, 2013, from http://pcaobus.org/about/pages/default.aspx

19. Quast, L. (n.d.) 4 Ways To Improve Your Hiring Process. Retrieved from: http://www.forbes.com/fdc/welcome_mjx.shtml

20. Report of the AAA/AAPLG Ad Hoc Committee to Assess the Supply and Demand for Accounting Ph.D.s. Retrieved from: http://free-doc-lib.com/book/supply-and-demand-for-accounting-ph-d-the-1.pdf

21. Robert Half (2013). Guide to Certifications for Accounting, Finance and Operations Management. Retrieved from: http://m.accountingweb.com/sites/default/files/guide_to_certifications_robert_half.pdf

22. Robert Half (2013). Robert Half Salary Guide. Retrieved from: http://www.rhi.com/SalaryGuides

23. Ruff, M., J. C. Thibodeau, \& J. C. Bedard. (2009). A Profession's Response to a Looming Shortage: Closing the Gap in the Supply of Accounting Faculty. Journal of Accountancy. 207(3), 36-40.

24. Ryan, R. (2010). Should I stay or should I go? Accounting Today. 24(16), 54-54.

25. Sahadi, J. (2013). CNNMoney. IRS role in Obamacare. Retrieved from: http://money.cnn.com/2013/05/28/pf/taxes/irs/-jea;tj-reform/index.html

26. Smith, J. (2012). Forbes.com. The Top Jobs for 2013. Retrieved from: http://www.forbes.com/sites/jacquelynsmith/2012/12/06/the-top-jobs-for-2013/

27. Telberg, R. (2013). CPA Trendlines. After an Economic Pause, the Accounting Industry Restarts Expansion Engines. Retrieved from: http://cpatrendlines.com/?s=after+an+economic+pause+the+accounting+industry+restarts+expansion+engi

28. U. S. Bureau of Labor Statistics. (2013). Accountants and Auditors: Occupational Outlook Handbook. Retrieved from: http://www.bls.gov/ooh/Business-and-Financial/Accountants-and-auditors.htm

29. U. S. Census Bureau. (2010). The Next Four Decades The Older Population in the United States: 2010 to 2050. Retrieved from: http://www.census.gov/prod/2010pubs/p25-1138.pdf

30. U. S. News \& World Report. (2013). Best Business Jobs Accountant. Retrieved from: http://money.usnews.com/careers/best-jobs/accountant 
NOTES 